\title{
Influence of Melia dubia Spatial Configurations on Quantitative and Qualitative Performance of Hybrid Napier (Pennisetum purpureum x $P$. americanum) and Soil Biota Status
}

\author{
D.R. Prajapati, N.S. Thakur*, V.R. Patel ${ }^{1}$, R.P. Gunaga, Lalit Mahatma ${ }^{2}$ and D.P. Patel ${ }^{3}$ \\ Department of Silviculture \& Agroforestry, College of Forestry, ${ }^{1}$ Department of Animal Nutrition, Vanbandhu College of \\ Veterinary Sciences \& Animal Husbandry, ${ }^{2}$ Dept. of Plant Pathology, N. M. College of Agriculture, ${ }^{3}$ Department of Natural \\ Resource Management, College of Forestry, Navsari Agricultural University, Navsari-396 450, India \\ *Email: drnsthakur74@gmail.com
}

\begin{abstract}
Study intended to develop suitable Melia dubia-hybrid Napier (HN) silvi-pasture and sole cropping systems through assessment of growth, physiology, forage yield, proximate and mineral principles of hybrid Napier under 5 years old M. dubia planted at $2 \times 2,3 \times 3,3 \times 2,4 \times 4$ and $4 \times 2 \mathrm{~m}$ spatial configurations. Study revealed that growth, physiological attributes, fresh and dry forage production, and proximate and mineral matter principles (average of two years; three harvests in each year) were higher under silvi-pasture systems as compared to sole cropping. Among silvi-pasture, $\mathrm{HN}$ attained significantly maximum plant height and number of leaves under M. dubia $(2 \times 2 \mathrm{~m})-\mathrm{HN}$, lengthiest leaf $(96.76 \mathrm{~cm})$ and widest leaf under $M$. dubia $(3 \times 2 \mathrm{~m})-\mathrm{HN}$, and tillers under sole HN cropping system. Among studied physiological attributes, specific leaf weight was maximum in sole $\mathrm{HN}$ cropping, chlorophyll content index was maximum of forage from $M$. dubia $(2 \times 2 \mathrm{~m})$ $\mathrm{HN}$ system, leaf area and leaf area index was maximum for clumps under M. dubia $(3 \times 2 \mathrm{~m})-\mathrm{HN}$ system. Significantly higher total fresh and dry forage yield was obtained from M. dubia $(2 \times 2 \mathrm{~m})-\mathrm{HN}$ and $M$. dubia $(3 \times 2 \mathrm{~m})-\mathrm{HN}$, respectively. Significantly maximum dry matter and crude fibre was in forage from sole cropping system. However, maximum crude protein, ether extract, nitrogen free extract, ash and nitrogen were recorded in forage from $M$. dubia $(2 \times 2 \mathrm{~m})-\mathrm{HN}$ system. Whereas, phosphorus and potassium was higher in forage from $M$. dubia ( $3 \times 2 \mathrm{~m})-\mathrm{HN}$ system. Integration of $\mathrm{HN}$ as understory crops, increased microbial populations in all land use systems. Among different silvi-pasture systems, closest spacing had more bacterial and actinomycetes populations, while fungi were highest under sole cropping. The study divulged out that tree-crop interactions under different $M$. dubia spatial configurations were positive. Hence, $\mathrm{HN}$ could be adopted as intercrop for higher forage yield and better nutritive quality.
\end{abstract}

Keywords: Melia dubia, Agroforestry, Hybrid napier, forage, Nutritive value, Soil biota

Estimates indicated that, there is a huge deficit of green and dry fodder in India. Over the years, this deficit is showing escalating trend from $62.76 \%$ (666 million MT) in year 2010 to $64.21 \%$ (759 million MT.) in year i.e. 2020 (Gol 2006). This deficit is the result of shrinkage of open land for grazing, urbanization and introduction of high yield cattle, which requires feeds in large quantity and of good quality as well (Birthal and Jha 2005). Ensuring an adequate supply of reasonable quality feed and fodder to livestock is one of the major challenges faced by country where dairying is largely the avocation of poor, especially women. Land allocation for cultivation of green fodder is limited and has hardly ever exceeded $5 \%$ of the gross cropped area (Gol 2015) due to increasing pressure for growing food grains, oil seeds and pulses. Hence, available land cannot directly be brought under fodder cultivation. In this case, agroforestry based silvi-pasture systems are advocated to address these issues. Such system promises healthy environment and rich biodiversity, which is an important support system on earth for sustainability of dairy enterprise (Pathak and Roy 1994,
Thakur et al 2005, 2015, Chauhan et al 2014). Besides the forage demand, the current production of raw materials for pulp and paper is 2.76 million tonnes, against the demand of 5.04 million tonnes, a shortfall of 45 per cent. The current demand is 13.2 million tonnes, which is still more staggering (Palsaniya et al 2009) and overall wood demand has been estimated more than 150 million cum (Shrivastava and Saxena 2017).

In this backdrop, development of silvi-pasture systems will not only help augment the raw material for wood-based industries but also in bridging the gap between demand and supply of quality fodder. For this the grass and tree species need to be screened based on the quantitative and qualitative evaluations which will provide insight to select compatible species. Hence, in the present study, Hybrid Napier (Pennisetum perpureum x $P$. americanum var. CO-3) was selected as intercrop to develop Melia dubia-HN based silvi-pasture systems. Melia dubia Cav. is indigenous to India and also found Bangladesh, Myanmar, Thailand, Mexico, Sri Lanka, Malaysia, Java, China, America, Philippines and 
Australia. It is multipurpose, fast-growing species, valued for its high-quality termite and fungus resistant timber for furniture, agricultural implements and house construction, plywood and pulp wood, owing to its high pulp recovery and exceptional fibre strength as compared other raw material (Parthiban et al 2009, Sinha et al 2019, Kumar et al 2017a). It has been reported compatible agroforestry ideotype (Jilariya et al 2017, Mohanty et al 2017, Thakur et al 2019) without any allelopathic effect (Kumar et al 2017b, Parmar et al 2019). Thus, intercrops like pulse, vegetable and medicinal/aromatic plants have been evaluated with this valuable multipurpose species (Bhusara et al 2018a \& b, Mohanty et al 2019, Jilariya et al 2019). But fodder intercropping studies are still lacking with respect to production, bio-physical interactions and forage quality. The study, intended to develop a compatible silvi-pasture system with appropriate spatial configuration.

\section{MATERIAL AND METHODS}

This study was carried out at the College of Forestry, Navsari Agricultural University, Navsari, Gujarat, India, during 2018-2019. Site is situated at $20.95^{\circ} \mathrm{N}$ latitude, $75.90^{\circ} \mathrm{E}$ longitude at an altitude of $10 \mathrm{~m}$ above the mean sea Arabian seashore. The system units of silvi-pasture systems were $M$. dubia [planted in 2014, the average growth attributes of $M$. dubia at Hybrid Napier (HN) planting-January, 2018 and at HN final harvest-November, 2019) under different spatial configurations are given in Table 1] as tree component and $\mathrm{HN}$ as intercrop. The experiment was conducted in randomized block design with 6 land uses i.e. $\mathrm{LU}_{1}$ to $\mathrm{LU}_{5}=M$. dubia at $2 \times 2,3 \times 2,3 \times 3,4 \times 2$ and $4 \times 4$ m, intercropped with $H N$, respectively and $L U_{6}=$ sole $H N$, with four replications. The treatment combinations so formed are referred here as silvi-pasture (M. dubia $+\mathrm{HN}$ ) systems. Healthy slips of $\mathrm{HN}$, Var. CO-3, were planted at $50 \times 50 \mathrm{~cm}$ spacing under each treatments $\left(L_{1}\right.$ to $\left.L_{6}\right)$ in January, 2018. Necessary agrotechniques were followed as suggested by Pandey and Roy
(2011).

Soil physico-chemical properties in silvi-pasture and sole cropping were estimated by taking samples in a zigzag manner to cover the entire treatment plot. Ten sub samples (cores) were taken randomly under each treatment and mixed together to make a representative (composite) sample. The average values of soil parameters along with estimation methods followed are presented in Table 2. Soil moisture (0-30 cm soil depth) was estimated gravimetrically using samples from all treatments and monthly data from transplanting till final harvest of $\mathrm{HN}$ are illustrated in Figures $1 \mathrm{a} \& \mathrm{~b}$. Photosynthetically active radiation (PAR) $\left(\mu \mathrm{Em}^{-2} \mathrm{~s}^{-1}\right)$ was measured fortnightly (on 9 points of each treatment, i.e. 3 points under the tree, 3 points between the trees, and 3 spots in the middle of tree diagonal) in each LU, using LICOR biosciences quantum sensor (LI-190) and monthly average values is illustrated are Figures $2 a$ \& b.

Growth, physiology and yield: Growth attributes viz., plant height, number of tillers/clump, number of leaves/tiller, leaf length and leaf width were recorded by taking 20 random samples $(n=20 ; 5$ plants $x 4$ replications from each treatment). Physiological parameters viz., specific leaf weight $\left[\left(\mathrm{SLW}\left(\mathrm{mg} / \mathrm{cm}^{2}\right)=\right.\right.$ Leaf dry weight $(\mathrm{mg}) /$ Leaf area $\left(\mathrm{cm}^{2}\right), \mathrm{n}=20 ; 5$ leaf discs $\times 4$ replications from each treatment], chlorophyll content index [using chlorophyll meter (Opti-sciences CCM 200, USA); $n=20 ; 4$ leaves $x 4$ replications from each treatment], leaf area $(n=20 ; 5$ leaves $x$ 4 replications from each treatment), leaf area index [using LAI-2200C plant canopy analyzer $(n=20$; 5 sampling points $x$ 4 replications from each treatment), were recorded by taking random samples. Similarly, fresh and dry $\mathrm{HN}$ forage yield was assessed by harvesting whole plot $(n=24 ; 4$ replications $x 6$ treatments) under each treatment, taking 3 harvests each yeari.e. 2018 and 2019.

Proximate principles and mineral matter: Proximate principles (\%) i.e. dry matter (DM), crude protein (CP), crude fibre (CF), ether extract (EE), ash content $(A C)$ and nitrogen-

Table 1. Average growth attributes of $M$. dubia under silvi-pasture systems having different spatial configurations at Hybrid Napier planting (2018) and final harvest (2019)

\begin{tabular}{|c|c|c|c|c|c|c|c|c|}
\hline \multirow[t]{3}{*}{ Land use systems } & \multicolumn{2}{|c|}{ Height (m) } & \multicolumn{2}{|c|}{$\mathrm{GBH}(\mathrm{cm})$} & \multicolumn{4}{|c|}{ Crown spread } \\
\hline & \multirow[t]{2}{*}{$*$} & \multirow[t]{2}{*}{$* *$} & \multirow[t]{2}{*}{$*$} & \multirow[t]{2}{*}{$* *$} & \multicolumn{2}{|c|}{ North-South } & \multicolumn{2}{|c|}{ East-West } \\
\hline & & & & & * & ** & * & ** \\
\hline $\mathrm{MD}(2 \times 2 \mathrm{~m})-\mathrm{HN}$ & 4.18 & 7.18 & 13.55 & 30.65 & 1.05 & 1.75 & 0.73 & 1.58 \\
\hline $\mathrm{MD}(3 \times 2 \mathrm{~m})-\mathrm{HN}$ & 6.33 & 9.25 & 21.18 & 42.63 & 1.68 & 2.84 & 1.29 & 1.73 \\
\hline $\mathrm{MD}(3 \times 3 \mathrm{~m})-\mathrm{HN}$ & 6.70 & 10.45 & 22.03 & 47.40 & 1.84 & 2.81 & 1.60 & 2.28 \\
\hline $\mathrm{MD}(4 \times 2 \mathrm{~m})-\mathrm{HN}$ & 5.50 & 9.50 & 20.48 & 47.35 & 2.08 & 3.61 & 1.23 & 1.75 \\
\hline $\mathrm{MD}(4 \times 4 \mathrm{~m})-\mathrm{HN}$ & 6.50 & 10.08 & 21.53 & 47.58 & 2.10 & 3.78 & 1.41 & 2.60 \\
\hline
\end{tabular}

*at Hybrid Napier planting; **at Hybrid Napier final harvest; $M D=M$. dubia; $\mathrm{HN}=$ Hybrid Napier 
free extract (NFE) as well as mineral matter constituents i.e. Nitrogen $(\mathrm{N})$, phosphorus $(\mathrm{P})$, and potassium $(\mathrm{K})$ were estimated by standard procedures (AOAC 2016).

Soil biota: The microbial population (bacteria, fungi and actinomycetes) was counted in each LU system by the standard plate count method (Seeley et al 1991) using formula: Total no. of microbes $/ g$ of soil $=$ No. of colonies in plate/volume of aliquot plated on agar medium $x$ dilution level.

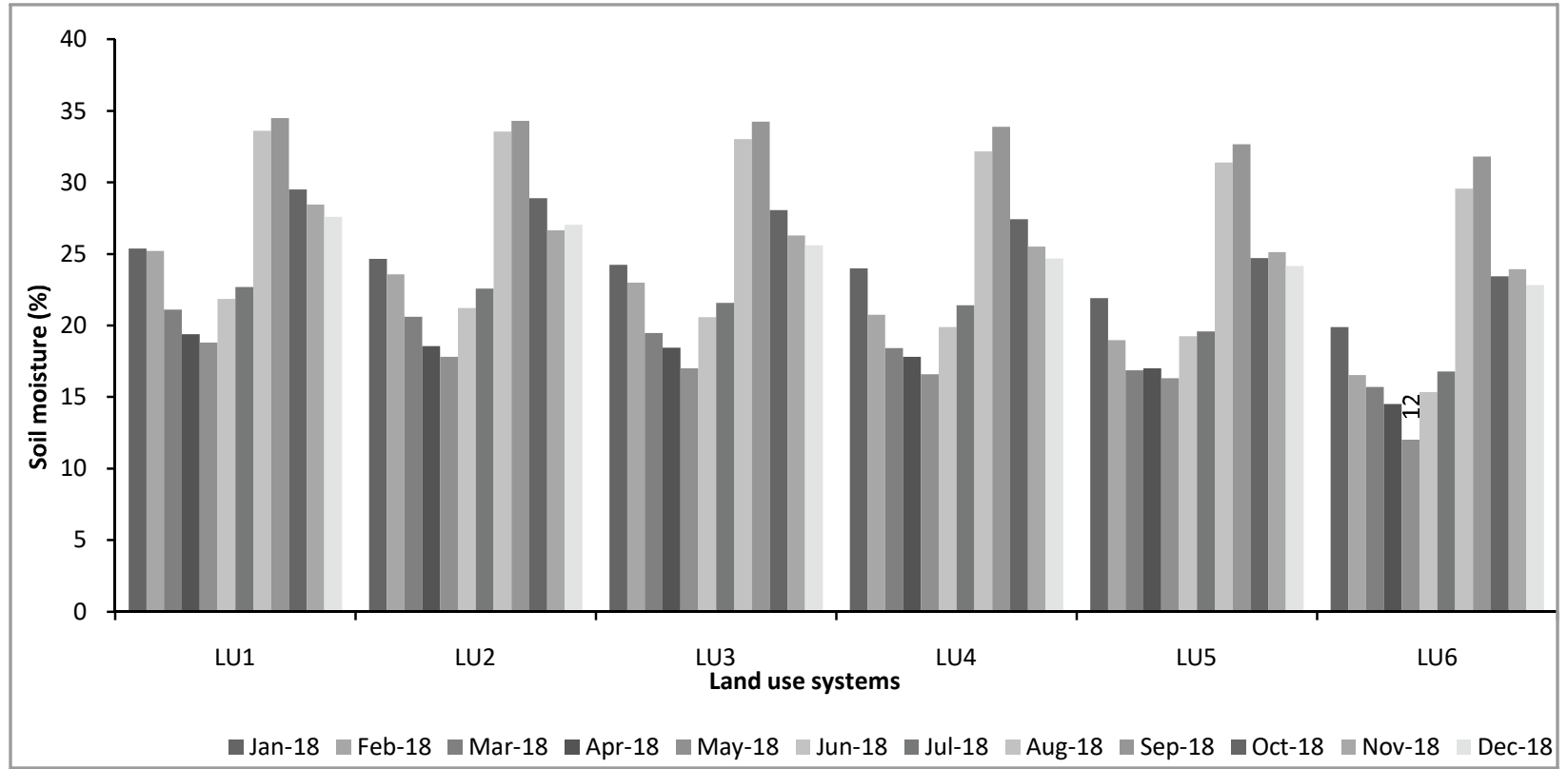

Fig. 1a. Average monthly soil moisture (\%) under M. dubia-Hybrid Napier based silvi-pasture and sole cropping systems during Jan-2019 to Nov-19 $\left[\mathrm{LU}_{1}=\right.$ M. dubia $(2 \times 2 \mathrm{~m})-\mathrm{HN}, \mathrm{LU}_{2}=$ M. dubia $(3 \times 2 \mathrm{~m})-\mathrm{HN}, \mathrm{LU}_{3}=$ M. dubia $(3 \times 3 \mathrm{~m})-\mathrm{HN}, \mathrm{LU}$ $=$ M. dubia $(4 \times 2 \mathrm{~m})-\mathrm{HN}, \mathrm{LU}_{5}=$ M. dubia $(4 \times 4)-\mathrm{HN}, \mathrm{LU}_{6}=$ Sole $\left.\mathrm{HN}\right]$

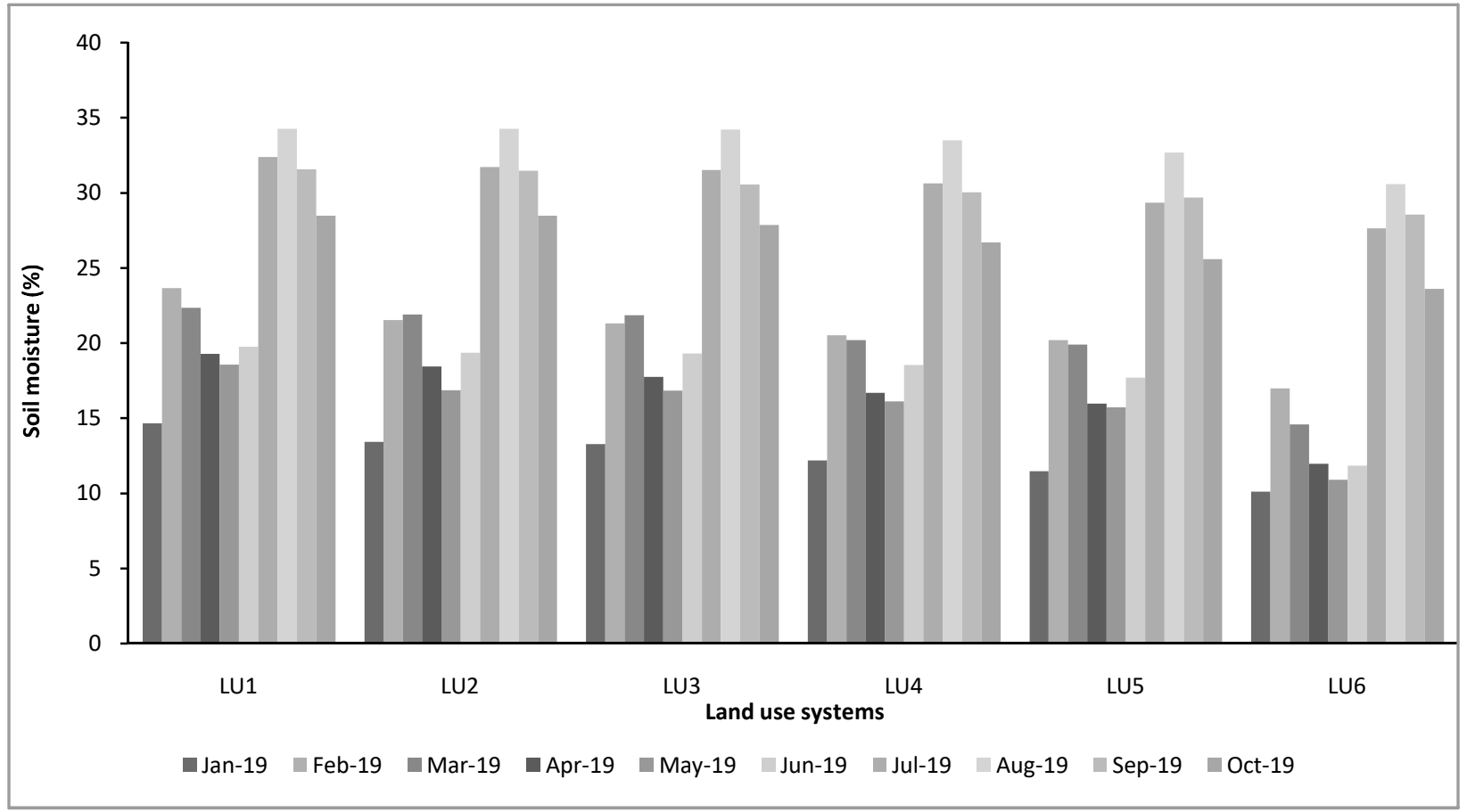

Fig. 1b. Average monthly soil moisture (\%) under M. dubia-Hybrid Napier based silvi-pasture and sole cropping systems during Jan-2019 to Oct-19 [LU $=$ M. dubia $(2 \times 2 \mathrm{~m})-\mathrm{HN}, \mathrm{LU}_{2}=$ M. dubia $(3 \times 2 \mathrm{~m})-\mathrm{HN}, \mathrm{LU}_{3}=$ M. dubia $(3 \times 3 \mathrm{~m})-\mathrm{HN}, \mathrm{LU} \mathrm{U}_{4}$ $=$ M. dubia $(4 \times 2 \mathrm{~m})-\mathrm{HN}, \mathrm{LU}_{5}=$ M. dubia $(4 \times 4)-\mathrm{HN}, \mathrm{LU}_{6}=\mathrm{Sole} \mathrm{HN]}$ 
Statistical analysis: The experimental data generated were subjected to the statistical analysis following randomized block design (RBD) and ANOVA $\left(Y_{i j}=\mu+a_{i}+b_{j}+e i j\right.$ where $i=1,2, \ldots \ldots ., t ; j=1,2, \ldots \ldots \ldots, n_{i} ; Y_{i j}=$ response of the $j^{\text {th }}$ individual unit (replication) belong to the $i^{\text {th }}$ group (treatment); $\mu=$ overall mean; ai= effect of treatment $i$ (difference with $\mu$ ); $b=$ effect of block j (difference with $\mu$ ); eij= error in measurement for treatment $i$ and block j) was constructed following Sheoran et al (1998). Duncan's multiple range test (DMRT) was used to compare the sets of means of each treatment at $P<0.05$ suing WASP (Web Agri Stat Package) Developed by Ashok Kumar Jangam and Pranjali Ninad Wadekar, Indian Council of Agricultural Research complex, Goa, India.

\section{RESULTS AND DISCUSSION}

Hybrid napier growth, physiology and yield: Growth, physiological and yield attributes (average of three consecutive harvests per year i.e. 2018 and 2019) of Hybrid Napier $(\mathrm{HN})$ varied significantly $(P<0.05)$ under $M$. dubia-HN silvi-pasture and sole cropping land use (LU) systems (Table

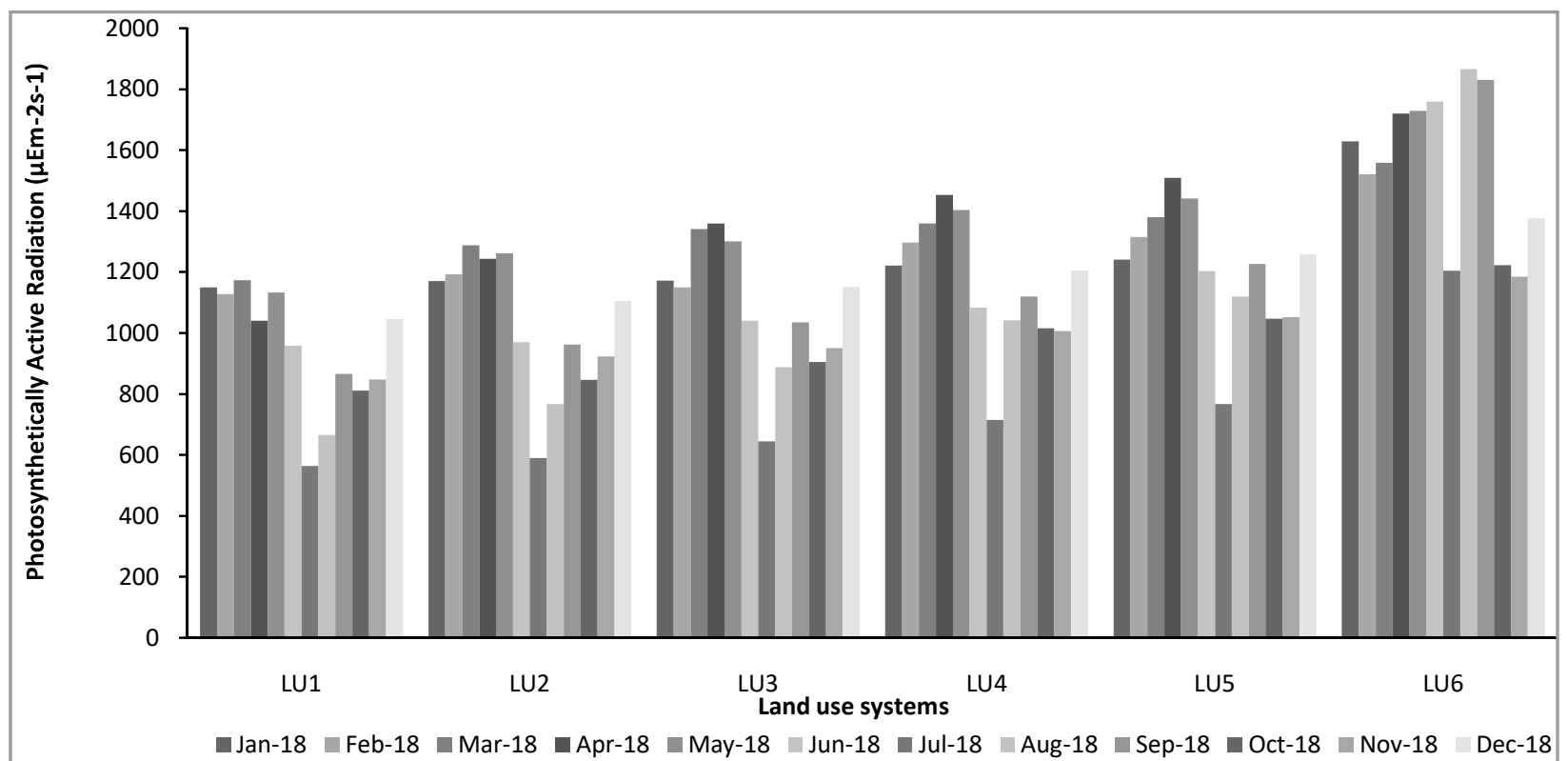

Fig. 2a. Average monthly Photosynthetically Active Radiation (PAR; $\mu$ Em-2s-1) under M. dubia-HN based silvi-pasture and sole cropping systems during Jan-2018 to Dec-19 $\left[\mathrm{LU}_{1}=M\right.$. dubia $(2 \times 2 \mathrm{~m})-\mathrm{HN}, \mathrm{LU}_{2}=M$. dubia $(3 \times 2 \mathrm{~m})-\mathrm{HN}, \mathrm{LU}=M$. dubia $(3 \times 3 \mathrm{~m})-\mathrm{HN}, \mathrm{LU}_{4}=$ M. dubia $(4 \times 2 \mathrm{~m})-\mathrm{HN}, \mathrm{LU}_{5}=$ M. dubia $(4 \times 4)-\mathrm{HN}, \mathrm{LU}_{6}=$ Sole HN]

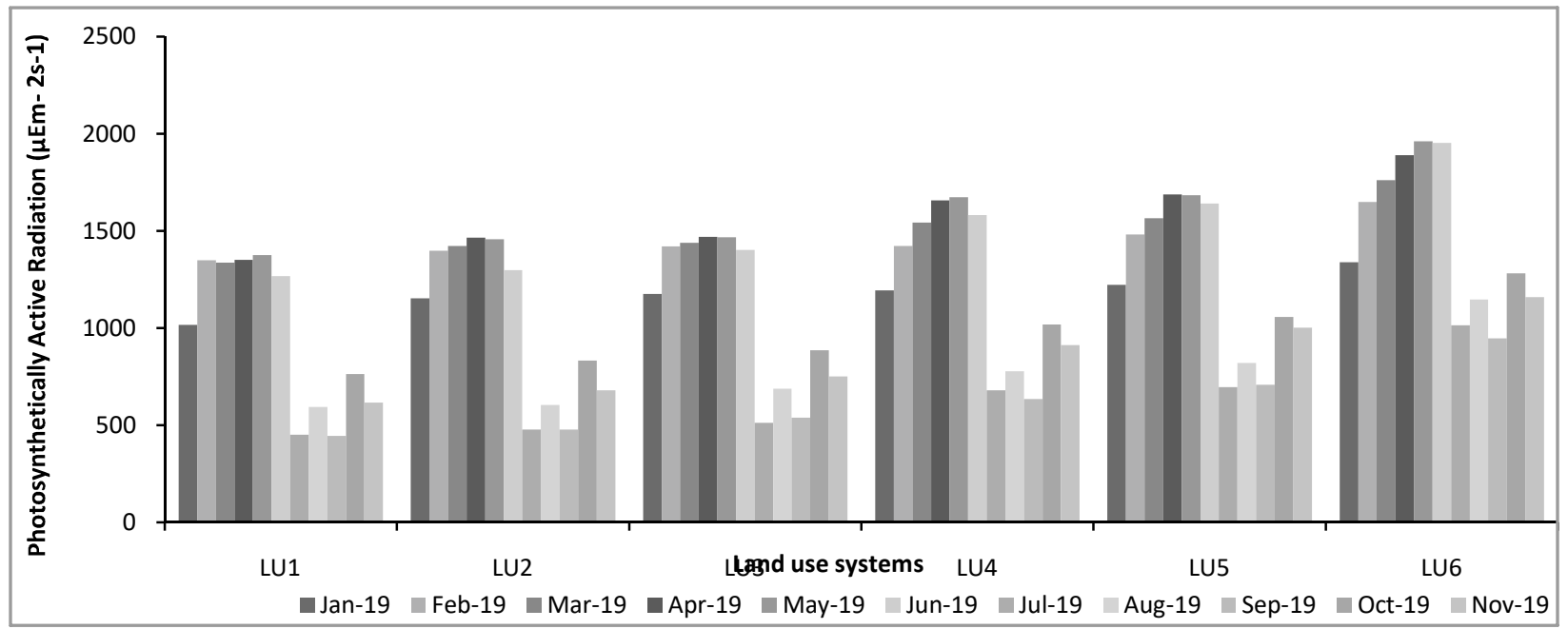

Fig. 2b. Average monthly Photosynthetically Active Radiation (PAR; $\mu E m-2 s-1)$ under M. dubia-HN based silvi-pasture and sole cropping systems during Jan-2019 to Nov-19 [LU $=M$. dubia $(2 \times 2 \mathrm{~m})-\mathrm{HN}, \mathrm{LU}_{2}=M$. dubia $(3 \times 2 \mathrm{~m})-\mathrm{HN}, \mathrm{LU}=M$. dubia $(3 \times 3 \mathrm{~m})-\mathrm{HN}, \mathrm{LU}_{4}=$ M. dubia $(4 \times 2 \mathrm{~m})-\mathrm{HN}, \mathrm{LU}_{5}=$ M. dubia $(4 \times 4)-\mathrm{HN}, \mathrm{LU}_{6}=$ Sole HN] 
3, Fig. 3a, b). Significantly superior plant height, number of tillers per clump, leaf length and leaf width of $\mathrm{HN}$ was under M. dubia-HN systems having $2 \times 2 \mathrm{~m}$ and $3 \times 2 \mathrm{~m}$ spatial configurations as compared other $M$. dubia geometries and sole cropping. HN attained maximum plant height (142.29 $\mathrm{cm})$ and number of leaves (9.29/tiller) under M. dubia $(2 \times 2$ m)-HN (Table 3). Maximum tillers (21.92/clump) were formed under sole HN cropping. Significantly lengthiest $(96.76 \mathrm{~cm})$ and widest leaf $(3.09 \mathrm{~cm})$ was developed by clumps under $M$. dubia $(3 \times 2 \mathrm{~m})-\mathrm{HN}$. The study deduced that $\mathrm{HN}$ growth parameters were lesser under silvi-pasture systems with wider spatial configurations (Table 3).

Specific leaf weight was maximum $\left(6.17 \mathrm{mg} / \mathrm{cm}^{2}\right)$ in sole HN cropping system (Table 4). Highest chlorophyll content index (47.08) was in forage from M. dubia $(2 \times 2 \mathrm{~m})-\mathrm{HN}$ system. Maximum leaf area $\left(188.26 \mathrm{~cm}^{2}\right)$ and LAI (13.98) was under M. dubia $(3 \times 2 \mathrm{~m})-\mathrm{HN}$, which was statistically at par with that attained under M. dubia $(2 \times 2 \mathrm{~m})$-HN system. The study indicated that SLW was least, whereas all other attributes were superior under silvi-pasture systems with narrow spatial configurations (Table 4). Fresh and dry forage productivity $\left(\mathrm{t} \mathrm{ha}^{-1}\right.$ year $\left.^{-1}\right)$ of $\mathrm{HN}$ was significantly $(P<0.05)$ highest (122.66 t ha $^{-1}$ year $\left.^{-1}\right)$ from M. dubia ( $\left.2 \times 2 \mathrm{~m}\right)$-HN LU (Fig. 3a). Significantly maximum dry forage productivity amounting to $27.55 \mathrm{t} \mathrm{ha}^{-1}$ year $^{-1}$ was from M. dubia $(3 \times 2 \mathrm{~m})$ $\mathrm{HN}$, which was at par with that provided by M. dubia $(2 \times 2 \mathrm{~m})-$ HN system (Fig. 3b).

Our study indicated that growth performance of $\mathrm{HN}$ was better under silvi-pasture systems. It may be ascribed to partial shade (Fig. 2a, b) under different M. dubia spatial configurations. Antony (2016) reported that increased level of artificial shade increased plant height, leaf length, leaf width

Table 2. Average soil physico-chemical properties (0-30 cm depth) under M. dubia-Hybrid Napiersilvi-pasture systems and sole cropping

\begin{tabular}{|c|c|c|c|c|c|c|}
\hline $\begin{array}{l}\text { Land use } \\
\text { systems }\end{array}$ & $\mathrm{pH}^{\prime}$ & $\begin{array}{l}\text { Electrical conductivity } \\
\left(\mathrm{dSm}^{-1}\right)^{\#}\end{array}$ & $\begin{array}{c}\text { Organic } \\
\text { carbon }(\%)^{s}\end{array}$ & $\begin{array}{l}\text { Nitrogen } \\
\left(\mathrm{kg} \mathrm{ha}^{-1}\right)^{*}\end{array}$ & $\begin{array}{l}\text { Phosphorus } \\
\left(\mathrm{kg} \mathrm{ha}^{-1}\right)^{\prime \prime}\end{array}$ & $\begin{array}{l}\text { Potassium } \\
\left(\mathrm{kg} \mathrm{ha}^{-1}\right)^{* *}\end{array}$ \\
\hline \multicolumn{7}{|c|}{ At HN planting (January, 2018) } \\
\hline $\mathrm{T}_{1}$ & 7.70 & 0.29 & 0.79 & 246.38 & 11.26 & 504.08 \\
\hline $\mathrm{T}_{2}$ & 7.65 & 0.24 & 0.77 & 236.77 & 10.96 & 504.76 \\
\hline $\mathrm{T}_{3}$ & 7.52 & 0.24 & 0.74 & 224.86 & 10.90 & 508.48 \\
\hline $\mathrm{T}_{4}$ & 7.52 & 0.23 & 0.70 & 212.46 & 10.96 & 510.86 \\
\hline $\mathrm{T}_{5}$ & 7.50 & 0.24 & 0.67 & 212.00 & 10.70 & 512.10 \\
\hline $\mathrm{T}_{6}$ & 7.34 & 0.33 & 0.57 & 230.57 & 13.99 & 615.89 \\
\hline \multicolumn{7}{|c|}{ At $\mathrm{HN}$ final harvest (November, 2019) } \\
\hline $\mathrm{T}_{1}$ & 7.39 & 0.26 & 0.82 & 229.74 & 10.62 & 477.13 \\
\hline $\mathrm{T}_{2}$ & 7.37 & 0.22 & 0.81 & 220.30 & 10.92 & 482.41 \\
\hline $\mathrm{T}_{3}$ & 7.33 & 0.19 & 0.80 & 217.11 & 10.80 & 495.76 \\
\hline $\mathrm{T}_{4}$ & 7.28 & 0.16 & 0.77 & 203.84 & 10.80 & 501.35 \\
\hline $\mathrm{T}_{5}$ & 7.26 & 0.16 & 0.74 & 189.76 & 10.38 & 515.64 \\
\hline $\mathrm{T}_{6}$ & 7.32 & 0.13 & 0.66 & 189.37 & 9.02 & 550.83 \\
\hline
\end{tabular}

$\mathrm{T}_{1}=M$. dubia $(2 \times 2 \mathrm{~m})-\mathrm{HN}, \mathrm{T}_{2}=M$. dubia $(3 \times 2 \mathrm{~m})-\mathrm{HN}, \mathrm{T}_{3}=M$. dubia $(3 \times 3 \mathrm{~m})-\mathrm{HN}, \mathrm{T}_{4}=M . d u b i a(4 \times 2 \mathrm{~m})-\mathrm{HN}, \mathrm{T}_{5}=M . d u b i a(4 \times 4 \mathrm{~m})-\mathrm{HN}, \mathrm{T}_{6}=\mathrm{Sole} \mathrm{HN} ; \mathrm{Potentiometric}$ method;" supernated liquid suspension of $1: 2.5$ soil water ratio method; ${ }^{\$}$ Walkley and Black's rapid titration method; *Alkaline potassium permanganate method; "Olsen's method;" $1 \mathrm{~N} \mathrm{NH}_{4} \mathrm{OAC}$ Extraction method

Table 3. Growth performance of hybrid napier $(\mathrm{HN})$ under M. dubia-HN based silvi-pasture and sole cropping systems

\begin{tabular}{|c|c|c|c|c|c|}
\hline Land use systems & $\begin{array}{l}\text { Plant height } \\
(\mathrm{cm})\end{array}$ & $\begin{array}{l}\text { Number of tillers } \\
\text { clump }^{-1}\end{array}$ & $\begin{array}{c}\text { Number of leaves } \\
\text { tiller }^{-1}\end{array}$ & $\begin{array}{l}\text { Leaf length } \\
\quad(\mathrm{cm})\end{array}$ & $\begin{array}{l}\text { Leaf width } \\
\quad(\mathrm{cm})\end{array}$ \\
\hline $\mathrm{MD}(2 \times 2 \mathrm{~m})-\mathrm{HN}$ & $142.29^{a}$ & $20.16^{b}$ & $9.29^{\mathrm{a}}$ & $94.64^{\mathrm{ab}}$ & $2.97^{b}$ \\
\hline $\mathrm{MD}(3 \times 2 \mathrm{~m})-\mathrm{HN}$ & $138.46^{\mathrm{ab}}$ & $21.66^{\mathrm{a}}$ & $9.14^{\mathrm{ab}}$ & $96.76^{a}$ & $3.09^{\mathrm{a}}$ \\
\hline $\mathrm{MD}(3 \times 3 \mathrm{~m})-\mathrm{HN}$ & $134.28^{b}$ & $15.17^{d}$ & $8.89^{\mathrm{bc}}$ & $93.29^{\mathrm{bc}}$ & $2.83^{\mathrm{c}}$ \\
\hline $\mathrm{MD}(4 \times 2 \mathrm{~m})-\mathrm{HN}$ & $121.09^{d}$ & $20.52^{\mathrm{b}}$ & $8.73^{\mathrm{c}}$ & $87.46^{d}$ & $2.68^{d}$ \\
\hline $\mathrm{MD}(4 \times 4 \mathrm{~m})-\mathrm{HN}$ & $127.62^{\mathrm{C}}$ & $19.15^{c}$ & $8.92^{b c}$ & $93.49^{\mathrm{bc}}$ & $2.86^{\mathrm{c}}$ \\
\hline Sole HN & $126.98^{\text {cd }}$ & $21.92^{\mathrm{a}}$ & $8.99^{b c}$ & $91.35^{\mathrm{c}}$ & $2.80^{\circ}$ \\
\hline $\operatorname{SEm}( \pm)$ & 1.86 & 0.30 & 0.08 & 0.79 & 0.03 \\
\hline
\end{tabular}

$\mathrm{T}_{1}=$ M. dubia $(2 \times 2 \mathrm{~m})-\mathrm{HN}, \mathrm{T}_{2}=M$. dubia $(3 \times 2 \mathrm{~m})-\mathrm{HN}, \mathrm{T}_{3}=M$. dubia $(3 \times 3 \mathrm{~m})-\mathrm{HN}, \mathrm{T}_{4}=M . d u b i a(4 \times 2 \mathrm{~m})-\mathrm{HN}, \mathrm{T}_{5}=M . d u b i a(4 \times 4 \mathrm{~m})-\mathrm{HN}, \mathrm{T}_{6}=\mathrm{Sole} \mathrm{HN} ; \mathrm{Means}$ with different superscript letter in the same column indicate significant difference $(p<0.05)$ according to Duncan's Multiple Range Test 
and leaf area index, whereas, number of tillers, number of leaves, and fodder yield of six cultivars of $\mathrm{HN}$ (CO-3, CO-4, Suguna, IGFRI-3, DHN-6 and PTH) were reduced under shade. In contrary, growth and yield in our study was higher under natural shade of M. dubia. DeBruyne et al (2011) reported that grass forage yield was greater under black walnuts and honey locusts tree canopy than under 70 per cent shade cloth (artificial shade). This indicate that, tree canopy shade increases forage fresh/dry biomass (Soares et al 2009, Barro et al 2012). The varying tree densities affect performance and production of under storey grasses. Earlier studies also inferred that tree canopy shade under agroforestry system favour intercrops resulting in enhanced growth and production (Gupta et al 2012, Paciullo et al 2011, DeBruyne et al 2011, Mohanty et al 2019, Thakur et al 2019).

Enhanced growth and herbage production of aromatic grasses has been reported under $M$. dubia based agroforestry systems due to beneficial effect of partial shade and better moisture availability (Thakur et al 2019, Mohanty et al 2019). Partial shade under silvi-pasture systems, moderate ambient microclimate i.e. air temperature, soil moisture and retention for longer time and reduction in the soil water evaporation especially due to low irradiance under closed tree spacings (Jilariya et al 2017, Thakur et al 2018). In present study these deductions are supported by available soil moisture (Fig. 1a, b) and reduced PAR (Fig. 2a, b).

Plants respond to resource limitations by allocating their biomass to those organs which are engaged in capturing these resources (Poorter et al 2012). The taller plants in silvipasture systems indicate a phototropism response to modify plant leaf distribution in order to help the plants receive enough light (Yang et al 2007). Under-storey plants in response to varying shade levels increase number of leaves (Rezai et al 2017). Likewise, intermediate light conditions (about $50 \%$ of full sun light) results in higher levels of biomass production in some species (Goncalves et al 2005).
Similarly, in the present study decreased PAR under silvipasture (Fig. 2a, b) increased number of leaves, leaf length and width and leaf area due to increase in radiation use efficiency. Thus, shade increases these growth-attributes for higher light interception, which may have ultimately resulted in vegetative growth of $\mathrm{HN}$ under $M$. dubia-HN silvi-pasture systems.

In present study, more trees in close spatial magnitudes might have produced more litter fall, which eventually released more nutrients into the soil due to high decomposition rate under shade owing to higher moisture retaining capacity (Dodd et al 2005, Jilariya et al 2017). The availability of nutrients and moisture for longer period improve intercrop growth and yield (Wilson 1996, Scholes and Archer 1997). Increased decomposition rate of organic matter increased $\mathrm{N}$ availability (Wilson and Wild 1995). Higher $\mathrm{N}$ availability under silvi-pasture LU may be attributed to directly $\mathrm{N}$ fixation by microbial communities (Catchpole and Blair 1990). Soil microbes itself store significant quantities of soil carbon and nitrogen in living biomass and their death make $\mathrm{N}$ readily available to crops (Duxbury et al 1989). Present findings are consistent with these studies where higher organic matter, $\mathrm{N}$ content (Table 2) and microbial colonies (Table 6 ) were observed under silvipasture LU than sole cropping systems. Light levels increase towards saturation, quantum yields (ratio of the number of photons emitted to the number of photons absorbed) decline, due to the inability of carbon metabolism to utilize fully the light energy absorbed by the leaf of $\mathrm{C}_{4}$ plants (Zhu et al 2010). Similar mechanism may have encountered in open plot where high sunlight did not yield biomass due to maximum light level.

Increased forage yield may also be assigned to twin facts i.e. water use efficiency by shaded grass and increased water availability through hydraulic lift by trees (DeBruyne et al 2011). High water use efficiency may also allow $C_{4}$ plants to

Table 4. Physiological attributes of hybrid napier (HN) under M. dubia-HN based silvi-pasture and sole cropping systems

\begin{tabular}{|c|c|c|c|c|}
\hline Land use systems & $\begin{array}{l}\text { Specific leaf weight (mg } \\
\left.\mathrm{cm}^{-2}\right)\end{array}$ & $\begin{array}{l}\text { Chlorophyll content } \\
\text { index (CCl) }\end{array}$ & $\begin{array}{c}\text { Leaf area } \\
\left(\mathrm{cm}^{2}\right)\end{array}$ & $\begin{array}{c}\text { Leaf area index } \\
\text { (LAI) }\end{array}$ \\
\hline $\mathrm{MD}(2 \times 2 \mathrm{~m})-\mathrm{HN}$ & $5.59^{c}$ & $47.08^{\mathrm{a}}$ & $177.86^{b}$ & $12.80^{\mathrm{b}}$ \\
\hline $\mathrm{MD}(3 \times 2 \mathrm{~m})-\mathrm{HN}$ & $5.64^{\circ}$ & $42.45^{\mathrm{b}}$ & $188.26^{a}$ & $13.98^{\mathrm{a}}$ \\
\hline $\mathrm{MD}(3 \times 3 \mathrm{~m})-\mathrm{HN}$ & $5.69^{c}$ & $39.99^{\circ}$ & $160.94^{d}$ & $8.36^{\mathrm{e}}$ \\
\hline $\mathrm{MD}(4 \times 2 \mathrm{~m})-\mathrm{HN}$ & $5.95^{\mathrm{b}}$ & $36.62^{d}$ & $142.71^{\mathrm{e}}$ & $9.91^{d}$ \\
\hline $\mathrm{MD}(4 \times 4 \mathrm{~m})-\mathrm{HN}$ & $5.94^{b}$ & $36.11^{\mathrm{d}}$ & $163.42^{\text {cd }}$ & $10.95^{\mathrm{c}}$ \\
\hline Sole HN & $6.17^{\mathrm{a}}$ & $33.28^{\mathrm{e}}$ & $169.08^{c}$ & $12.77^{\mathrm{b}}$ \\
\hline SEm $( \pm)$ & 0.04 & 0.57 & 2.28 & 0.28 \\
\hline
\end{tabular}

$\mathrm{T}_{1}=$ M. dubia $(2 \times 2 \mathrm{~m})-\mathrm{HN}, \mathrm{T}_{2}=$ M. dubia $(3 \times 2 \mathrm{~m})-\mathrm{HN}, \mathrm{T}_{3}=M$. dubia $(3 \times 3 \mathrm{~m})-\mathrm{HN}, \mathrm{T}_{4}=M$. dubia $(4 \times 2 \mathrm{~m})-\mathrm{HN}, \mathrm{T}_{5}=M$. dubia $(4 \times 4 \mathrm{~m})-\mathrm{HN}, \mathrm{T}_{6}=\mathrm{Sole} \mathrm{HN} ; \mathrm{Means}$ with different superscript letter in the same column indicate significant difference $(p<0.05)$ according to Duncan's Multiple Range Test 
exhibit more flexible allocation patterns, for example allocating proportionally more biomass to shoots in moist environments (silvi-pasture systems), or to roots in dry environments (Open plot) (Taylor et al 2010). Superior growth and yield attributes of $\mathrm{HN}$ under silvi-pasture system in the present investigation, may be due to the fact that $M$. dubia in younger age of 4-5 years moght have created favorable microclimatic conditions. Therefore, HN performed well under different $M$. dubia spatial configurations compared to open or sole HN cropping systems.

Integration of woody and non-woody components together leads to complex interactions among themselves at various bio-physical domains such as light, space, water, nutrients, etc. Modifications in micro-environment by trees, directly or indirectly influence various vital physiological processes of under-storey crops (Chauhan et al 2013, Zhang et al 2014). Adaptable plants change morpho-physiological attributes in response to changing environments, including larger and thinner leaves with about three-fold increase in total chlorophyll content. The synthesis and degradation of photosynthetic pigments are associated with adaption to changing environments (Taiz and Zeiger 2002). Lower SLW in silvi-pasture systems may be ascribed to reduced irradiance (Figures 3.1a \& b, 3.2) due to tree shade with fewer mesophyll cells and stomata per unit area, and more intercellular air space. Shade reduces cell wall concentration due to unavailability of photosynthates for secondary cell wall development (Fales and Fritz 2007).

The increased leaf area under shade is the result of longer leaves because of leaf elongation to capture more sun light under reduced irradiance (Kephart et al 1992, Mohanty et al 2019). Sanderson and Nelson (1995) Reducing light in a stepwise manner results in longer leaves with a larger area and lower SLW, a greater leaf elongation rate, and reduced dry matter deposition in high yield per tiller and low yield per tiller genotypes of tall fescue. These findings are in congruence with the present study.

Similar to our study, higher chlorophyll content under shade has been reported earlier (Rezai et al 2017). This demonstrate the ability of plant to maximize the light harvesting capacity under light-deficit conditions and the efficient use of light captured in photosynthesis with decreased respiration costs for maintenance (Dai et al 2009). The lower $\mathrm{CCl}$ in sole crops might be due to excess irradiance that caused greater degradation or photooxidation of chlorophyll and consequently decrease chlorophyll levels (Goncalves et al 2005). Increased leaf area and leaf area index while reduced specific leaf dry weight in shade compared to plants grown in full sun have also been reported (Lin et al 2001, Mohanty et al 2019, Thakur et al 2019). These findings are in agreement with present study. Overall, change in microclimatic condition under narrow and

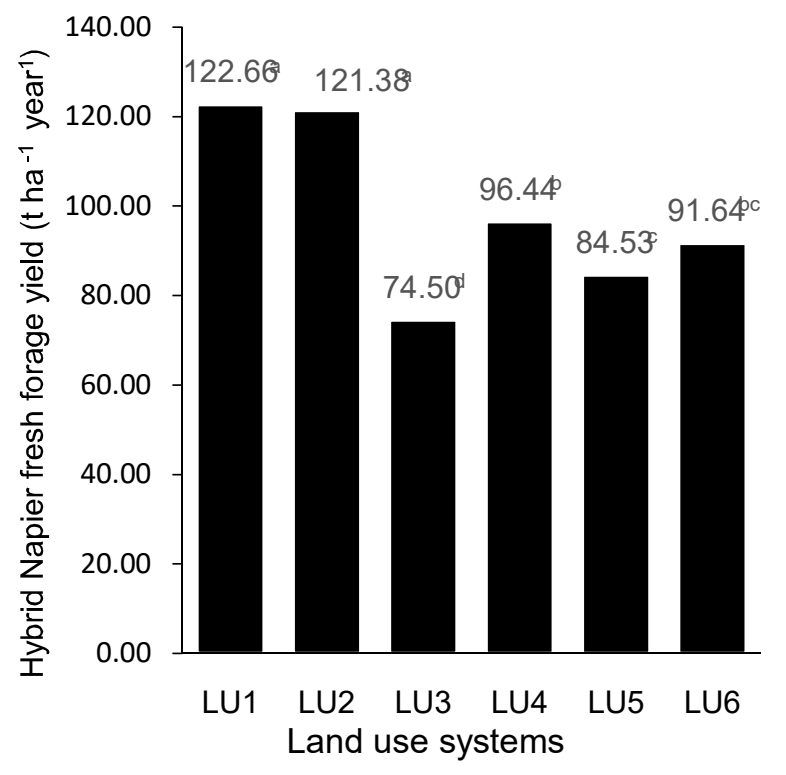

(a)

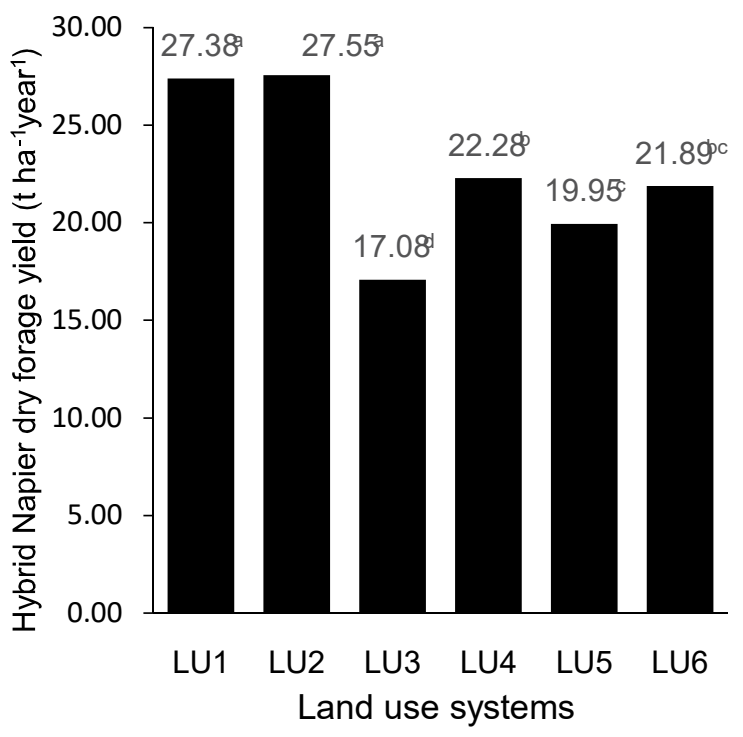

(b)

Fig. 3. Hybrid Napier fresh $\left[a(S E m( \pm)=2.57)\right.$ and dry $\left[b(\operatorname{SEm}( \pm)=2.57)\right.$ forage yield $\left(\mathrm{t}^{-1} \mathrm{yar}^{-1}\right)$ under $M$. dubia-HN based silvi-pasture and sole cropping systems $\left[\mathrm{LU}_{1}=M\right.$. dubia $(2 \times 2 \mathrm{~m})-\mathrm{HN}, \mathrm{LU}_{2}=M$. dubia $(3 \times 2 \mathrm{~m})-\mathrm{HN}, \mathrm{LU}_{3}=M . d u b i a(3 \times 3$ $\mathrm{m})-\mathrm{HN}, \mathrm{LU}_{4}=$ M. dubia $(4 \times 2 \mathrm{~m})-\mathrm{HN}, \mathrm{LU}_{5}=M$. dubia $(4 \times 4)-\mathrm{HN}, \mathrm{LU}_{6}=$ Sole HN]; Means with different superscript letter with data labels in each bar indicate significant difference $(p<0.05)$ according to Duncan's Multiple Range Test 
wider spatial configurations influenced the HN physiological attributes by altering PAR, moisture (Fig. 2a, b), nutrients availability and soil microbial populations (Tables 2,6$)$.

HN forage qualitative attributes: Results on $\mathrm{HN}$ forage qualitative attributes (average of three consecutive harvests per year i.e. 2018 and 2019), evinced that forage proximate principles namely dry matter (DM), crude protein (CP), crude fibre (CF), ether extract (EE), ash content (AC), nitrogen free extract (NFE), $\mathrm{N}$ (nitrogen), $\mathrm{P}$ (phosphorus) and $\mathrm{K}$ (potassium) experienced significant $(P<0.05)$ influence of silvi-pasture and sole HN cropping systems (Table 5). Significantly maximum DM and CF to the tune of 23.89 and $31.39 \%$, respectively was obtained in $\mathrm{HN}$ forage from sole cropping system. However, maximum CP (9.36\%), EE (2.19\%) and $A C(14.25 \%)$ was recorded in $\mathrm{HN}$ forage harvested from M. dubia $(2 \times 2 \mathrm{~m})$-HN system. Similarly, NFE content was also maximum (47.23\%) in forage harvested from $M$. dubia $(2 \times 2 \mathrm{~m}$ )-HN (Table 5). Maximum forage $\mathrm{N}$ $(1.50 \%)$ content was in samples from M. dubia $(2 \times 2 \mathrm{~m})-\mathrm{HN}$ system. Whereas, $\mathrm{P}$ and $\mathrm{K}$ percentage $(0.21$ and $3.82 \%$, respectively) was in forage from $M$. dubia ( $3 \times 2 \mathrm{~m})$-HN LU.

The ranges of DM, CP, CF, EE, N and P of HN (var. CO3) forage in the present study are in agreement, while ash and $\mathrm{K}$ contents are higher to those reported by Antony and Thomas (2014). Low pasture quality impairs the productivity of ruminant livestock and present study suggested that integration of $\mathrm{HN}$ under $M$. dubia silvi-pasture systems not only increased the overall DM production but also increased $\mathrm{CP}, \mathrm{EE}$, ash, N, P and $\mathrm{K}$ content. Higher NDF i.e. total fibre levels (cell wall) are advocated to slower forage digestion rate and result in lower voluntary intake (Ball et al 2001), dry matter intake and energy content (Saha et al 2017). Therefore, lower crude fibre in forage from silvi-pasture system is better while considering forage quality in intercrops.
Sanderson and Nelson (1995) found that reduced light result in reduced dry matter deposition in high yield per tiller and low yield per tiller genotypes of tall fescue. CP contents of $10 \%$ is sufficient for medium level of production from ruminants (Subba 1999) and the present study indicated higher $\mathrm{CP}$ in silvi-pasture system which may decrease the cost of additional concentrated feeds to the animals. The lower amount of CP or $\mathrm{N}$ content in sole cropping systems may be due to the low soil moisture availability (Fig. 1a, b) that directly affects the mineral nutrition of plants by mechanisms (Lemaire and Gastal 2009). Higher N availability under silvi-pasture may also be due to direct effect of $\mathrm{N}$ fixation in the under-storey grass by microbial communities (Catchpole and Blair 1990). Many other researchers have also reported higher $\mathrm{CP}$ or nitrogen content (irrespective of nitrogen fertilization) under shady environmental condition (Cruz 1997, Guenni et al 2008), which are in accordance with the present investigation. The higher moisture availability under agroforestry systems boost rapid organic matter breakdown and increase $\mathrm{N}$ availability (Wilson 1996, Thakur et al 2019). The eventual availability of more $\mathrm{N}$ availability to $\mathrm{HN}$ under $\mathrm{M}$. dubia tree canopy might have increased $\mathrm{N}$ content of intercrops as compared to the sole grown crop. Apparently in present study, the better fertility status (Table 2) and microbial populations (Table 6) are evident to support these inferences.

Ether extract contains crude fat which is high density source of energy and alcohols, waxes, terpenes, steroids, pigments, ester, aldehydes, and other lipids (Ball et al 2001). In present study it was higher in forage under M. dubia silvipasture than sole cropping systems. Increased EE may be due to higher availability of nitrogen due to high decomposition and $\mathrm{N}$ cycling rate under silvi-pasture induced the pigments amount in plants and that, ultimately, increased the EE percent in silvi-pasture (Barros 2010). Forage quality

Table 5. Proximate principles and mineral content (\%) of hybrid napier (HN) under M. dubia-HN based silvi-pasture and sole cropping systems

\begin{tabular}{lcccccccccc}
\hline Land use systems & DM & CP & CF & EE & AC & NFE & N & $P$ & $K$ \\
\hline $\mathrm{T}_{1}$ & $22.19^{\mathrm{e}}$ & $9.36^{\mathrm{a}}$ & $26.98^{\mathrm{f}}$ & $2.19^{\mathrm{a}}$ & $14.25^{\mathrm{a}}$ & $47.23^{\mathrm{a}}$ & $1.50^{\mathrm{a}}$ & $0.20^{\mathrm{a}}$ & $3.77^{\mathrm{ab}}$ \\
$\mathrm{T}_{2}$ & $22.51^{\mathrm{d}}$ & $9.13^{\mathrm{b}}$ & $27.85^{\mathrm{e}}$ & $2.03^{\mathrm{b}}$ & $13.98^{\mathrm{ab}}$ & $47.02^{\mathrm{a}}$ & $1.46^{\mathrm{b}}$ & $0.21^{\mathrm{a}}$ & $3.82^{\mathrm{a}}$ \\
$\mathrm{T}_{3}$ & $22.71^{\mathrm{cd}}$ & $8.43^{\mathrm{c}}$ & $28.62^{\mathrm{d}}$ & $1.92^{\mathrm{c}}$ & $13.94^{\mathrm{ab}}$ & $47.09^{\mathrm{a}}$ & $1.35^{\mathrm{c}}$ & $0.19^{\mathrm{a}}$ & $3.69^{\mathrm{ab}}$ \\
$\mathrm{T}_{4}$ & $22.91^{\mathrm{c}}$ & $8.22^{\mathrm{c}}$ & $30.05^{\mathrm{c}}$ & $1.81^{\mathrm{d}}$ & $13.75^{\mathrm{bc}}$ & $46.16^{\mathrm{b}}$ & $1.32^{\mathrm{c}}$ & $0.18^{\mathrm{b}}$ & $3.60^{\mathrm{b}}$ \\
$\mathrm{T}_{5}$ & $23.40^{\mathrm{b}}$ & $7.93^{\mathrm{d}}$ & $30.62^{\mathrm{b}}$ & $1.80^{\mathrm{d}}$ & $13.49^{\mathrm{c}}$ & $46.17^{\mathrm{b}}$ & $1.27^{\mathrm{d}}$ & $0.17^{\mathrm{b}}$ & $3.36^{\mathrm{c}}$ \\
$\mathrm{T}_{6}$ & $23.89^{\mathrm{a}}$ & $6.83^{\mathrm{e}}$ & $31.39^{\mathrm{a}}$ & $1.52^{\mathrm{e}}$ & $13.11^{\mathrm{d}}$ & $47.15^{\mathrm{a}}$ & $1.09^{\mathrm{e}}$ & $0.15^{\mathrm{c}}$ & $3.24^{\mathrm{c}}$ \\
SEm $( \pm)$ & 0.08 & 0.06 & 0.15 & 0.03 & 0.12 & 0.22 & 0.01 & 0.004 & 0.06 \\
\hline
\end{tabular}

$\mathrm{T}_{1}=$ M. dubia $(2 \times 2 \mathrm{~m})-\mathrm{HN}, \mathrm{T}_{2}=M$. dubia( $\left.3 \times 2 \mathrm{~m}\right)-\mathrm{HN}, \mathrm{T}_{3}=M$. dubia $(3 \times 3 \mathrm{~m})-\mathrm{HN}, \mathrm{T}_{4}=M . d u b i a(4 \times 2 \mathrm{~m})-\mathrm{HN}, \mathrm{T}_{5}=M . d u b i a(4 \times 4 \mathrm{~m})-\mathrm{HN}, \mathrm{T}_{6}=\mathrm{Sole} \mathrm{HN} ; \mathrm{DM}=\mathrm{Dry}$ matter; $\mathrm{CP}=$ Crude protein; $\mathrm{CF}=$ Crude fibre; $\mathrm{EE}=\mathrm{Ether}$ extract; $\mathrm{AC}=$ Ash content; NFE=Nitrogen free extract; $\mathrm{N}=$ Nitrogen; $\mathrm{P}=\mathrm{Phosphorus;} \mathrm{K}=\mathrm{Potassium}$; Means with different superscript letter in the same column indicate significant difference $(p<0.05)$ according to Duncan's Multiple Range Test 
of grasses increased by shade with a small decrease in fiber concentration, an increase in digestibility, and a large increase in $\mathrm{N}$ concentration. Under shaded conditions, leaf area may be increased and leaf-area expansion may be prolonged, allowing only limited photosynthate for growth of secondary cell walls. Thus, shade may cause lower cell wall (fibre) concentration and increased forage quality (Kephart and Buxton 1993). The reduced PAR delays the maturation process of fodder grasses (Bos and Neuteboom 1998) and delays plant maturity, thereby reducing the fibre content (Pierson et al 1990). Higher cell wall content i.e. crude fibre decrease the in-vitro dry matter digestibility (O'Shea 1968). Therefore, higher HN CF content under sole cropping systems may impair the DM intake and lower the feed conversion ratio. The grasses under silvi-pasture relatively have high ash content i.e. total minerals content as compared to sole cropping systems. It may be due to higher uptake of potassium under silvi-pasture systems, which is major part of ash. Apparently, in the present study, forage $\mathrm{K}$ content was higher under silvi-pasture systems compared to sole crop. Previous studies have reported higher uptake of K (Guenni et al 2008) and $P$ (Belsky 1992, Cruz 1997) by plants under shade which are in consistence with our study. NFE content of forage grasses is directly affected by $C P, C F, E E$, and AC of the grasses. Therefore, increase in these proximate principles decreases the NFE content of the forage grass. Higher NFE content in HN under silvi-pasture systems indicate it as energy rich source (Sukhadiya et al 2020).

Fungal population (cfu; colony forming units/g of soil): Fungal population (two years average of each season) was minimum $\left(0.25 \times 10^{6} \mathrm{cfu} / \mathrm{g}\right)$ in $M$. dubia $2 \times 2 \mathrm{~m}$ configuration among different spatial configurations (before planting $\mathrm{HN}$ in M. dubia plantations and open filed later $\mathrm{HN}$ sole crop systems) (Table 6). Fungal population increased with increase in M. dubia spacing and was maximum (3.25 x $10^{6}$ $\mathrm{cfu} / \mathrm{g}$ ) in open field. After HN intercropping, similar trend was observed in all the seasons viz., summer, monsoon and winter. Maximum fungal population count of 3.88, 2.88 and $3.75 \times 10^{6} \mathrm{cfu} / \mathrm{g}$ was observed in summer and monsoon under $\mathrm{HN}$ sole cropping and in winter under M. dubia $(4 \times 4$ m)-HN LU, respectively. M. dubia (2 x $2 \mathrm{~m})$-HN silvi-pasture system showed minimum fungal count of $0.38,0.88$ and 1.50 $x 10^{6} \mathrm{cfu} / \mathrm{g}$ in three seasons, respectively. However, it increased from summer, monsoon to winter season.

Bacterial population (cfu/g): Bacterial population, before $\mathrm{HN}$ planting, was maximum $\left(61 \times 10^{7} \mathrm{cfu} / \mathrm{g}\right)$ in $2 \times 2 \mathrm{~m} \mathrm{M}$. dubia spatial configuration. It was in decreasing order with increase in spatial arrangement of M. dubia and minimum $\left(4 \times 10^{7}\right.$

Table 6. Soil microbial population (cfu/ml) under M. dubia-HN based silvi-pasture and sole cropping systems

\begin{tabular}{|c|c|c|c|c|c|}
\hline \multirow[t]{2}{*}{ Types of microbes } & \multirow[t]{2}{*}{ Land use systems } & \multirow[t]{2}{*}{ At $\mathrm{HN}$ planting } & \multicolumn{3}{|c|}{$\begin{array}{c}\text { Average seasonal (2018-19) variation in microbia } \\
\text { population after HN planting }\end{array}$} \\
\hline & & & Summer & Monsoon & Winter \\
\hline \multirow[t]{6}{*}{ Fungi population x $10^{6}(\mathrm{cfu} / \mathrm{g})$} & $\mathrm{T}_{1}$ & 0.25 & 0.38 & 0.88 & 1.50 \\
\hline & $\mathrm{T}_{2}$ & 1.25 & 1.50 & 1.00 & 2.25 \\
\hline & $\mathrm{T}_{3}$ & 1.25 & 1.75 & 1.13 & 2.25 \\
\hline & $\mathrm{T}_{4}$ & 1.50 & 1.75 & 1.38 & 2.38 \\
\hline & $\mathrm{T}_{5}$ & 2.00 & 2.25 & 2.00 & 3.75 \\
\hline & $\mathrm{T}_{6}$ & 3.25 & 3.88 & 2.88 & 3.50 \\
\hline \multirow[t]{6}{*}{ Bacterial population $\times 10^{7}(\mathrm{cfu} / \mathrm{g})$} & $\mathrm{T}_{1}$ & 61.00 & 144.88 & 300.00 & 187.13 \\
\hline & $\mathrm{T}_{2}$ & 57.00 & 117.50 & 267.38 & 173.75 \\
\hline & $\mathrm{T}_{3}$ & 38.75 & 116.13 & 241.00 & 100.38 \\
\hline & $\mathrm{T}_{4}$ & 27.00 & 78.13 & 166.63 & 88.63 \\
\hline & $\mathrm{T}_{5}$ & 21.75 & 66.63 & 141.75 & 47.63 \\
\hline & $\mathrm{T}_{6}$ & 4.00 & 40.25 & 105.75 & 16.75 \\
\hline \multirow[t]{6}{*}{ Actinomycetes population $\times 10^{6}(\mathrm{cfu} / \mathrm{g})$} & $\mathrm{T}_{1}$ & 4.00 & 10.50 & 4.38 & 30.75 \\
\hline & $\mathrm{T}_{2}$ & 3.00 & 8.13 & 4.25 & 19.13 \\
\hline & $\mathrm{T}_{3}$ & 2.75 & 3.13 & 3.50 & 14.25 \\
\hline & $\mathrm{T}_{4}$ & 1.00 & 2.25 & 1.13 & 6.75 \\
\hline & $\mathrm{T}_{5}$ & 0.75 & 1.25 & 1.00 & 4.25 \\
\hline & $\mathrm{T}_{6}$ & 0.00 & 0.38 & 0.13 & 1.38 \\
\hline
\end{tabular}


cfu/g) was in open field (Table 6). Similar trend was also observed in all the seasons viz., summer, monsoon and winter after intercropping HN (Table 6). Bacterial population was highest $\left(114.88,300\right.$ and $187.13 \times 10^{7} \mathrm{cfu} / \mathrm{g}$ in all seasons, respectively) in M. dubia ( $2 \times 2 \mathrm{~m})$-HN silvi-pasture, whereas lowest was in sole $\mathrm{HN}$ cropping system.

Actinomycetes population (cfu/g): Actinomycetes populations, before $\mathrm{HN}$ intercropping (Table 6) was maximum ( $4 \times 10 \mathrm{cfu} / \mathrm{g})$ in M. dubia $(2 \times 2 \mathrm{~m})$-HN silvi-pasture system. Count decreased with increase in spatial configuration and no count was recorded in open field. Similar trend was observed after $\mathrm{HN}$ intercropping in all the seasons. M. dubia $(2 \times 2 \mathrm{~m})-\mathrm{HN}$ LU harbored highest population $\left(10.50,4.38\right.$ and $30.75 \times 10^{6} \mathrm{cfu} / \mathrm{g}$, in three seasons, respectively) and minimum was in sole $\mathrm{HN}$ system. The soil microbial population study substantiated that integration of $\mathrm{HN}$ as understory crops, increased microbial populations in all LU systems. Further, among different seasons, fungi and actinomycetes populations were highest in winter season, while bacterial population was maximum in monsoon season. Among different silvi-pasture systems, closest spacings had more bacterial and actinomycetes populations, while fungi were highest under sole cropping. Agroforestry practices are advocated as techniques that can be used to conserve and improve soil organic matter (Ross 1993) by increasing soil microbial biomass and enhance plant residue inputs (Amatya et al 2002, Lee and Jose 2003, Mao and Zeng 2013).

Many factors i.e. environmental, and soil conditions; composition of the soil micro-organism population; and chemical quality of the litter affect soil organic matter decomposition rate (Swift et al 1979), which is directly proportional to the nutrient release to the soil (Dhanya et al 2013). Rates of litter and soil organic matter mineralization and nutrient availability to plants may be greater under trees, due to higher litter inputs, higher soil moisture, and lower soil and air temperatures (Menezes et al 2002). These studies are evident for the increased microbial populations obtained in the present investigations. Low population of microorganism is found in the soil with low organic matter (Bhattarai et al 2015). Thus, present study substantiates that varying $M$. dubia densities created congenial development conditions for soil biota thereby improving the soil health. Further, inclusion of $\mathrm{HN}$ improved the microbial populations.

\section{CONCLUSIONS}

The growth, physiological attributes, fresh and dry forage production, and proximate and mineral matter principles and qualitative attributes (average of two years; three harvests in each year) were higher under silvi-pasture systems as compared to sole cropping. Study also substantiated that integration of $\mathrm{HN}$ under varying $M$. dubia configurations, increased microbial populations in all LU systems. Among different silvi-pasture LU systems, closest spacing had more bacterial and actinomycetes populations, while fungi were highest under sole cropping. The study evinced out that tree-crop interactions under different $M$. dubia spatial configurations were positive and hence $\mathrm{HN}$ could be adopted as intercrop for better quantitative and qualitative attributes.

\section{ACKNOWLEDGEMENT}

The authors are thankful to Dr. P. K. Shrivatstava, Dean, ASPEE College of Horticulture and Forestry, and Dr. V. B. Kharadi, Dean, Vanbandhu College of Veterinary Sciences and Animal Husbandry, NAU, Navsari, Gujarat, India for providing necessary support for this study. Authors are highly thankful to Dr. Ashok Kumar, Scientist E, Division of Forest Genetics \& Tree Improvement, Forest Research Institute Dehradun, Uttarakhand, India, for supply of $M$. dubia seed.

\section{REFERENCES}

Amatya G, Chang SX, Beare MH and Mead DJ 2002. Soil properties under a Pinus radiata-ryegrass silvopastoral system in New Zealand. Part II. C and $\mathrm{N}$ of soil microbial biomass, and soil $\mathrm{N}$ dynamics. Agroforestry System 54: 149-160.

Antony S 2016. Shade tolerance, nitrogen nutrition, and harvest management in hybrid napier under rainfed condition. Ph.D. Thesis, KeralaAgricultural University, Kerala, India, pp 1-322.

AOAC 1995. Animal feeds. In: Official methods of analysis of Association of Official Analytical Chemists 1 Vol. $6^{\text {th }}$ edition, VA 22201-3301 pp 1-18.

Ball DM, Collins M, Lacefield GD, Martin NP, Mertens DA, Olson KE, Putnam DH, Undersander DJ and Wolf MW 2001. Understanding forage quality. American Farm Bureau Federation Publication 1-01, Park Ridge, IL.

Barro RS, Varella AC, Lemaire G, Borges de Medeiros R, Carlos de Saibro J, Nabinger C, Bangel FV and Carassai JI 2012. Forage yield and nitrogen nutrition dynamics of warm-season native forage genotypes under two shading levels and in full sunlight. Revista Brasileira de Zootecnia 41(7): 1589-1597.

Barros IC 2010. Bromatological composition of Buffel grass cultivars in different seasons subjected to nitrogen fertilization. Dissertation (M.Sc. Animal science)- Universidade Estadual de Montes Claros, Janaúba, Minas Gerais, Brazil, pp 1-63.

Belsky AJ 1992. Effects of trees on nutritional quality of understorey gramineous forage in tropical savannas. Tropical Grasslands 26: $12-20$.

Bhattarai A, Bhattarai B and Pandey S 2015. Variation of soil microbial population in different soil horizons. Journal of Microbiology and Experimentation 2(2): 75-78.

Bhusara JB, Dobriyal MJ, Thakur NS, Gunaga RP and Tandel MB 2018b. Performance of okra (Abelmoschus esculentus L. Moench) under different spatial arrangements of Melia composita based agroforestry system. International Journal of Current Microbiology and Applied Sciences 7(5): 3533-3542.

Bhusara JB, Dobriyal MJ, Thakur NS, Sondarva RL and Prajapati DH 2018a. Growth and yield performance of green gram under Melia composita plantations. Journal of Pharmacognosy and Phytochemistry 7(3): 1490-1494. 
Birthal PS and Jha AK 2005. Economic losses due to various constraints in dairy production in India. Indian Journal of Animal Sciences 75: 1476-1480.

Bos HJ and Neuteboom JH 1998. Morphological analysis of leaf and tiller number dynamics of wheat (Triticum aestivum L.), responses to temperature and light intensity. Annals of Botany 81(1): 131-139.

Catchpole DW and Blair GJ 1990. Forage tree legumes. II Investigation of nitrogen transfer to an associated grass using a split-root technique. Australian Journal of Agricultural Research 41: 531-537.

Chauhan SK, Dhillon WS, Singh N and Sharma R 2013. Physiological behaviour and yield evaluation of agronomic crops under agri-horti-silviculture system. International Journal of Plant Research 3(1): 1-8.

Chauhan SK, Singh A, Sikka SS, Tiwana US, Chauhan R and Saralch HS 2014. Yield and quality assessment of annual and perennial fodder intercrops in leucaena alley farming system. Range Management and Agroforestry 35(2): 230-235.

Cruz P 1997. Effect of shade on the growth and mineral nutrition of a $\mathrm{C}_{4}$ perennial grass under field conditions. Plant and Soil 188: 227-237.

Dai Y, Shen Z, Liua Y, Wang L, Hannaway D and Lu H 2009. Effects of shade treatments on the photosynthetic capacity, chlorophyll fluorescence, and chlorophyll content of Tetrastigma hemsleyanum Diels et Gilg. Environmental and Experimental Botany 65: 177-182.

DeBruyne SA, Feldhake CM, Burger JA and Fike JH 2011. Tree effects on forage growth and soil water in an Appalachian silvopasture. Agroforestry System 83(2): 189-200.

Dhanya B, Vishwanath S and Purushothaman S 2013. Decomposition and nutrient release dynamics of Ficus benghalensis $\mathrm{L}$. litter in traditional agroforestry systems of Karnataka, southern India. ISRN Forestry.

Dodd MB, McGowan AW, Power IL and Thorrold BS 2005. Effects of variation in shade level, shade duration and light quality on perennial pastures. New Zealand Journal of Agricultural Research 48(4): 531-543.

Duxbury JM, Smith MS and Doran JM 1989. Soil organic matter as a source and a sink of plant nutrients. In: Dynamics of soil organic matter in tropical ecosystems (Eds. Coleman DC, Oades JM and Uehara G) NifTAL Project, University of Hawaii, USA, pp 3367.

Fales SL and Fritz JO 2007. Factors affecting forage quality. In: Forages: the science of grassland agriculture (Eds. Barnes, RF, Nelson, CJ, Moore KJ and Collins M), $6^{\text {th }}$ edition, Blackwell Publishing, Oxford, UK, pp 569-580.

Gedroc JJ, McConnaughay KDM and Coleman JS 1996. Plasticity in root/shoot partitioning: optimal, ontogenetic, or both? Functional Ecology 10(1): 44-50.

Gol 2006. Report of the working group on animal husbandry and dairying. Eleventh five year plan (2007-12), Planning Commission of India, Government of India. https://niti.gov.in/ planningcommission.gov.in/docs/aboutus/committee/wrkgrp11 /wg11_rpanim.pdf (accessed 10 April 2020).

Gol 2015. Land-Use Statistics 2014-15. Department of Agriculture, Cooperation \& Farmers Welfare, Ministry of Agriculture and Farmers Welfare, Government of India.

Goncalves JFC, Barreto DCS, Santos JrUM, Fernandes AV, Sampaio PTB and Buckeridge MS 2005. Growth, photosynthesis and stress indicators in young rosewood plants (Aniba rosaeodora Ducke) under different light intensities. Brazilian Journal of Plant Physiology 17: 325-334.

Guenni O, Seiter S and Figueroa R 2008. Growth responses of three Brachiaria species to light intensity and nitrogen supply. Trop. Grasslands 42: 75-87.

Gupta B, Thakur NS and Chib B 2012. Survival and growth of exotic grasses under plantations of Eucalyptus tereticornis in north- west Himalaya. Indian Journal of Forestry 35(2): 181-186.

Jilariya DJ, Thakur NS and Gunaga RP 2017. Quantitative and qualitative attributes of Aloe vera Linn. grown under Melia composita Willd. and sole cropping systems. Indian Journal of Ecology 44(5): 451-455.

Jilariya DJ, Thakur NS, Singh N and Gunaga RP 2019. Economics of cultivation of Melia dubia Cav.-Aloe vera L. silvi-medicinal model. Indian Journal of Agroforestry 21(2): 35-40.

Kephart KD and Buxton DR 1993. Forage quality responses of $C_{3}$ and $\mathrm{C}_{4}$ perennial grasses to shade. Crop Science 33: 831-837.

Kephart KD, Buxton DR and Taylor SE 1992. Growth of $\mathrm{C}_{3}$ and $\mathrm{C}_{4}$ perennial grasses under reduced irradiance. Crop Science 32: 1033-1038.

Kumar A, Shrivastava P, Sharma S, Dobhal S, Rana A and Kumar R 2017a. Development of high yielding varieties of Melia dubia Cav. (Syn. Melia composita Benth.). Indian Forester 143(11): 1203-1206.

Kumar D, Thakur NS and Gunaga RP 2017b. Effects of leaf aqueous extract and leaf litter of Melia composita Willd. on black gram [Vigna mungo (L.) Hepper]. Allelopathy Journal 41(1): 127-140.

Lee $\mathrm{KH}$ and Jose S 2003. Soil respiration and microbial biomass in a pecan-cotton alley cropping system in Southern USA. Agroforestry System 58: 45-54.

Lemaire G and Gastal F 2009. Quantifying crop responses to nitrogen deficiency and avenues to improve nitrogen use efficiency. In: Crop physiology: Applications for genetic improvement and agronomy, (Eds. Sadras VO and Calderini DF), Adelaide:Academic Press, Elsevier, pp 171-199.

Lin $\mathrm{CH}$, McGraw ML, George MF and Garrett HE 2001. Nutritive quality and morphological development under partial shade of some forage species with agroforestry potential. Agroforestry System 53: 269-281.

Mao R and Zeng D 2013. Effect of land-use change from cropland to poplar-based agroforestry on soil properties in a semiarid region of northeast China. Fresenius Environmental Bulletin 22(4a): 1077-1084.

Menezes RSC, Salcedo IH and Elliot ET 2002. Microclimate and nutrient dynamics in a silvopastoral system of semiarid northeastern Brazil. Agroforestry System 56: 27-38.

Mohanty S, Thakur NS, Gunaga RP, Dobriyal MJ and Desai BS 2017. Value addition in Cymbopogon spp. to enhance the financial flows from Cymbopogon spp.-Melia dubia Cav. based silvimedicinal and sole cropping systems. Indian Journal of Ecology 44(6): 812-816.

Mohanty S, Thakur NS, Gunaga RP and Gajbhiye N 2019. Influence of Melia dubia Cav. spatial geometries on growth, herbage yield and essential oil constituents of Cymbopogon martinii (Roxb.) Wats. Journal of Essential Oil Bearing Plants 22(3): 630-648.

O'Shea J, Ribeiro MAV and Moran MA 1968. Relationships between digestibility (in vitro), crude fibre and cellulose content of some animal feeds. Irish Journal of Agricultural Research 7(2): 173181.

Paciullo DSC, Fernandes PB, Gomide CAM, Castro CRT, Sobrinho FS and Carvalho CAB 2011. The growth dynamics in Brachiaria species according to nitrogen dose and shade. Revista Brasileira de Zootecnia 40(2): 270-276.

Palsaniya DR, Dhyani SK, Tewari RK, Singh R and Yadav RS 2009. Marketing issues and constraints in agroforestry. In: Agroforestry: natural resource sustainability, livelihood and climate moderation (Eds. Chaturvedi OP, Venkatesh A, Yadav RS, Alam B, Dwivedi RP, Singh R and Dhyani SK), Satish Serial Publishing House, India, pp. 563-577.

Pandey KC and Roy AK 2011. Forage Crops Varieties. Indian Grassland and Fodder Research Institute (ICAR), Jhansi, India.

Parmar AG, Thakur NS and Gunaga RP 2019. Melia dubia Cav. leaf litter allelochemicals have ephemeral allelopathic proclivity. Agroforestry System 93(4): 1347-1360.

Parthiban KT, Bharathi AKR, Seenivasan K and Kamala Rao MG 
2009. Integrating Melia dubia in agroforestry farms as an alternate pulpwood species. APA News 34, pp 3-4.

Pathak PS and Roy MM 1994. Silvopastoral system of production. A technical Bulletin, IGFRI, Jhansi, India, 55p.

Pierson EA, Mack RN and Black RA 1990. The effect of shading on photosynthesis, growth, and regrowth following defoliation for Bromus tectorum. Oecologia 84(4): 534-543.

Poorter H, Karl JN, Peter BR, Jacek O, Pieter P and Liesje M 2012. Biomass allocation to leaves, stems and roots: Meta-analyses of interspecific variation and environmental control. New Phytologist 193: 30-50.

Rezai S, Etemadi N, Nikbakht A, Yousefi M and Majid MM 2017. Effect of light intensity on leaf morphology, photosynthetic capacity, and chlorophyll content in Sage (Salvia officinalis L.). Horticultural Science and Technology 36(1): 46-57.

Ross SM 1993. Organic matter in tropical soils: current conditions, concerns and prospects for conservation. Progress in Physical Geography 17(3): 265-305.

Saha U, Sonon L, Hancock D, Hill N, Stewart L and Heusner G 2017. Common terms used in animal feeding and nutrition, UGA Cooperative Extension Bulletin 1367, University of Georgia.

Sanderson MA and Nelson CJ 1995. Growth of tall fescue leaf blades in various irradiances. European Journal of Agronomy 4: 197203.

Scholes RJ and Archer SR 1997. Tree-grass interactions in savannas. Annual Review of Ecology and Systematic 28: 517544.

Seeley HW and VanDemark PJ 1981. Microbes in action: A laboratory manual of microbiology, San Francisco: Freeman, $385 \mathrm{p}$.

Sheoran OP, Tonk DS, Kaushik LS, Hasija RC and Pannu RS 1998. Statistical software package for agricultural research workers. In: Recent advances in information theory (Eds. Hooda DS and Hasija RC), Statistics \& computer applications. Department of Mathematics Statistics, CCS Haryana Agricultural University, Hisar, pp. 139-143.

Shrivastava S and Saxena AK 2017. Wood is Good: but, is India doing enough to meet its present and future needs? Centre for Science and Environment, New Delhi, India, 45p.

Sinha SK, Chaudhari PA, Thakur NS, Jha SK, Patel DP and Dhaka RK 2019. Melia dubia Cav. wood properties vary with age and influence the pulp and paper quality. International Wood Products Journal 10(4): 139-148.

Soares AB, Sartor LR, Adami PF, Varella AC, Fonseca $L$ and Mezzalira JC 2009. Influence of luminosity on the behavior of eleven perennial summer forage species. Revista Brasileira de Zootecnia 38: 443-451.

Subba DB 1999. Tree fodders and browse plants as potential nutrient suppliers for ruminants. In: Livestock and fisheries research: Proceedings of the $3^{\text {rd }}$ National Workshop (Eds. Neopane SP and Khanal RC), Nepal Agricultural Research Council,
Kathmandu, Nepal, pp 97-109.

Sukhadiya ML, Thakur NS, Patel VR, Gunaga RP, Kharadi VB, Tyagi KK and Singh S 2020. Provenance variations in proximate principles, mineral matter, total phenols and phytochemicals of Melia dubia drupes: an unexplored alternate livestock feed stock. Journal of Forestry Research 32(1): 119-131.

Swift MJ, Heal OW and Anderson JM 1979. Decomposition in terrestrial ecosystems. In: Studies in ecology (Eds. Anderson DJ, Greig-smith P and Pitelka FA), $5^{\text {th }}$ Vol. University of California Press, Berkeley, pp 167-219.

Taiz L and Zeiger E 2002. Plant Physiology, $3^{\text {rd }}$ edition. Sinauer Associates, Sunderland, MA, USA, 690p.

Taylor SH, Hulme SP, Rees M, Ripley BS, Woodward FI and Osborne CP 2010. Ecophysiological traits in $\mathrm{C}_{3}$ and $\mathrm{C}_{4}$ grasses: a phylogenetically controlled screening experiment. New Phytologist 185: 780-791.

Thakur NS, Attar SK, Gupta NK and Gupta B 2015. Fodder availability from traditional agri-silvi-horticulture systems: requirement and deficit w.r.t. livestock status in mid hills of Western Himalayas-A case study. Journal of Tree Sciences 34(2): 22-27.

Thakur NS, Gupta NK and Gupta B 2005. An appraisal of biological diversity in agroforestry systems in North-Western Himalaya. Indian Journal of Ecology 32(1): 7-12.

Thakur NS, Jilariya DJ, Gunaga RP and Singh S 2018. Positive allelospoly of Melia dubia Cav. spatial geometry improve quantitative and qualitative attributes of Aloe vera L. Industrial Crops and Products 119: 162-171.

Thakur NS, Mohanty S, Gunaga RP and Gajbhiye NA 2019. Melia dubia Cav. spatial geometries influence the growth, yield and essential oil principles content of Cymbopogon flexuosus (Nees Ex Steud.) W. Watson. Agroforestry System 94: 985-995

Wilson JR 1996. Shade-stimulated growth and nitrogen uptake by pasture grasses in a subtropical environment. The Australian Journal of Agricultural Research 47: 1075-1093.

Wilson JR and Wild DWM 1995. Nitrogen availability and grass yield under shade environments. In: Integration of ruminants into plantations systems in Southeast Asia (Eds. Mullen BF and Shelton HM) ACIAR Proceedings No 64, Canberra, Australia, pp 42-48.

Yang XY, Ye XF, Liu GS, Wei HQ and Wang Y 2007. Effects of light intensity on morphological and physiological characteristics of tobacco seedlings. The Journal of Applied Ecology 18(11): 2642-2645

Zhang S, Jiang H, Zhao H, Korpelainen H and Li C 2014. Sexually different physiological responses of Populus cathayana to nitrogen and phosphorus deficiencies. Tree Physiology 34(4): 343-354.

Zhu XG, Long SP and Ort DR 2010. Improving photosynthetic efficiency for greater yield. Annual Review of Plant Biology 61: 235-261. 